\title{
Fourteenth Addenda to Criticism of the Current Science in the World
}

\author{
Pejman Malekinejad
}

\begin{abstract}
In this article, some facts related to psychiatry and my health were reviewed and the cause and remedial actions for my schizophrenia were mentioned. It was deduced that I felt HEALTHY with my entertainments. Furthermore, some facts about sexual medicine were illustrated. Also some scientific problems of Iran were mentioned. It was concluded that Iran and I will not become anything in the science, I have no intelligence and Iran and I will not become anything in general. Also two petitions were introduced in this paper. In addition, it was deduced that the only way for the scientific advancement of Iran is to make Iran a state of USA.
\end{abstract}

Keywords: Health, Schizophrenia, Crazy, DEPRESSIVE REALISM, Petition, Science.

\section{INTRODUCTION}

$\mathrm{V}$ oice of America (VOA Persian) has issued an article [1] that is in the same line with this paper. In fact, that article from VOA Persian confirms this paper. Also Eminent Crown Prince of Iran, Reza Pahlavi has a saying from Atamalek Joveini about Iran Islamic Regime as "They came and dug approves this paper.

\section{DISCUSSION}

I have my own entertainments which are available in my website [3]. When somebody wastes his/her time on entertainments or similarly with family, then he/she has no time for study, work and other activities. Therefore, according to the principles of DEPRESSIVE REALISM, he/she must get happy. With these entertainments I feel HEALTHY.

Hollywood is full of movies about DEPRESSIVE REALISM. At one end, there are movies like "The Silence of the Lambs, 1991", "Rain Man, 1988", "A Beautiful Mind, 2001", "The Iron Lady, 2011" and etc. In these movies intelligent people got mental disorders according to the principles of DEPRESSIVE REALISM. The message of great movie of "The Silence of the Lambs, 1991" is that if you do not understand anything like a lamb, then you will be

Manuscript received on 26 March 2021 | Revised Manuscript received on 30 March 2021 | Manuscript Accepted on 15 April 2021 | Manuscript published on 30 April 2021.

* Correspondence Author

Pejman Malekinejad*, Department of Materials Science and Engineering, Kerman Graduate University of Technology, Kerman, Iran. Email: pejmanmalekinejad2@gmail.com

(c) The Authors. Published by Lattice Science Publication (LSP). This is an open access article under the CC-BY-NC-ND license (http://creativecommons.org/licenses/by-nc-nd/4.0/) and burned and killed and took away and went" [2] which

slaughtered. At the other end, there are animations like "Droopy, 1943" which show that application of the principles of DEPRESSIVE REALISM causes the society not to advance. In summary in this animation, Droopy dog is in competition with other larger, more intelligent, more active and stronger dogs and in all these competitions, the droopy dog wins according to the principles of DEPRESSIVE REALISM. An episode of such type can be seen in YouTube [4, 5 and 6]. Therefore, their society will never advance and they will remain animal forever and will never become humans. Anyway I laugh very much when watching this animation. Droopy is an animated character from the golden age of American animation. The very iconic quote of Droopy Dog is "I'M SO HAPPY" which is clear in Fig. 1. In one of episodes of this animation called "Blackboard Jumble" [7], droopy dog tries to make mental disorder for his teacher because he is jealous of the teacher science. One concept that the teacher taught to droopy and caused his jealousy was $3=3$ which was written on the blackboard. The behavior of this teacher after catching mental disorder is very similar to me. In another episode of this animation, droopy dog is in competition with a group of other dogs to catch a fox. These group of dogs are all larger, more intelligent, more active and stronger dogs than droopy and try very much to catch the fox but they are not successful at all. Whereas droopy wins the completion and catch a group of foxes without any effort. This episode is available in YouTube [8, 9 and 10]. The song of "Labkhand" from Mr. Dariush Eghbali is very similar to this "Droopy Dog" animation. This song is available in YouTube [11].

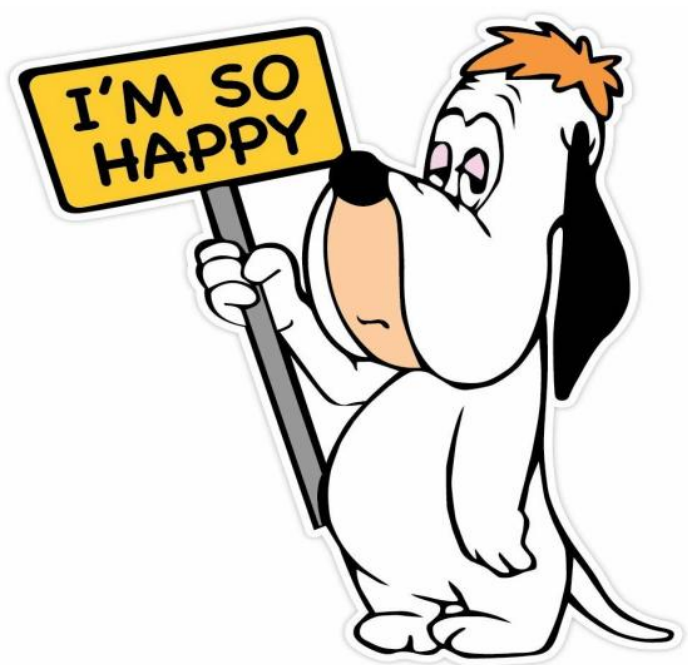

Fig. 1 - Droopy Dog with its iconic quote.

Published By:

Retrieval Number: 100.1/ijamst.B3003021221

DOI: 10.54105/ijamst.B3003.041221

Journal Website: www.ijamst.latticescipub.com

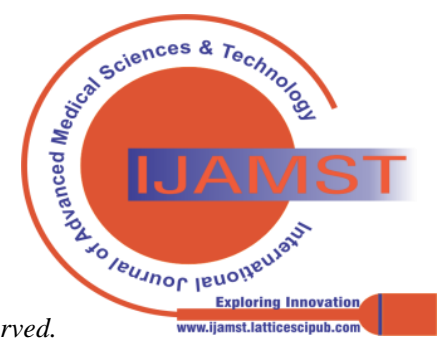


The "Sadder but Wiser" effect or DEPRESSIVE REALISM principles can be truly seen in Iranian society since the official news agency of TABNAK officially says that Iranian managers employ weak people [12]. TABNAK news agency is approved by Iran government. Anyway down with Iran regime for this DEPRESSIVE REALISM. However, life like an animal is not valuable at all. In Iran everybody behaves according to the principles of DEPRESSIVE REALISM in this way that the university professor lowers the grades of intelligent person, the manager does not give the job to intelligent person, the friend leaves the intelligent person, the father takes intelligent person to the psychiatrists and etc.

Fig. 2 is from BABYLON PICTURE DICTIONARY for crazy. He spins his finger around his ear to say that you are crazy. Also, he mocks everybody. He escapes since the people make him crazy. He uses magic to produce illusions and hallucinations. BABYLON PICTURE DICTIONARY is a valid, reputable and top international dictionary. Now I suppose that you could send me to madhouse. But the world understands that you, yourself are crazy. Fig. 2 from BABYLON PICTURE DICTIONARY shows this fact very good. According to the principles of DEPRESSIVE REALISM, the reason why intelligent people catch mental disorders is that all the people are jealous of such minds and therefore try to make a mental disorder for those intelligent persons and try to destroy those minds. This is because people think that everything is brain and science and they are the most important things.
The people think that if they have brain and science, then they will reach everything. This is completely wrong in Iran since the most important thing is politics in Iran because money, power and other benefits of political activities is extremely higher than any other activities in Iran. For example, as I have previously mentioned [13], the worth of Khamenei as Iran leader (200 Billion USD) is approximately twice more than the worth of richest person in the world as Mr. Jeff Bezos (116.9 Billion USD) who is known as the founder of AMAZON as world giant technology company [14]. Furthermore, Khamenei has control of Iran military and for example guns, missiles, war aircrafts, bombs and so on which Mr. Jeff Bezos does not have them. People cannot withstand and bear that a brain works so well and try to make a mental disorder for that intelligent person. It is to say that the intelligent people are mentally ill and in this way they appear crazy. These mental disorders are made to show that intelligent people seem crazy. People make mental disorders for intelligent persons to say that do not be honored of your brain since the psychological facts show that you have a mental disorder. But all the world knows that those who make these mental disorders are crazy themselves. People want to make psychiatric and medical documents, dossiers and records for that genius to show that he is mentally ill and this is why they send him to psychiatrist. The age of such frauds is over. Fig. 2 is from BABYLON PICTURE DICTIONARY shows this fact very good. Anyway the people say that I have schizophrenia and my manuscripts of psychiatrist are in my website [15 and 16].

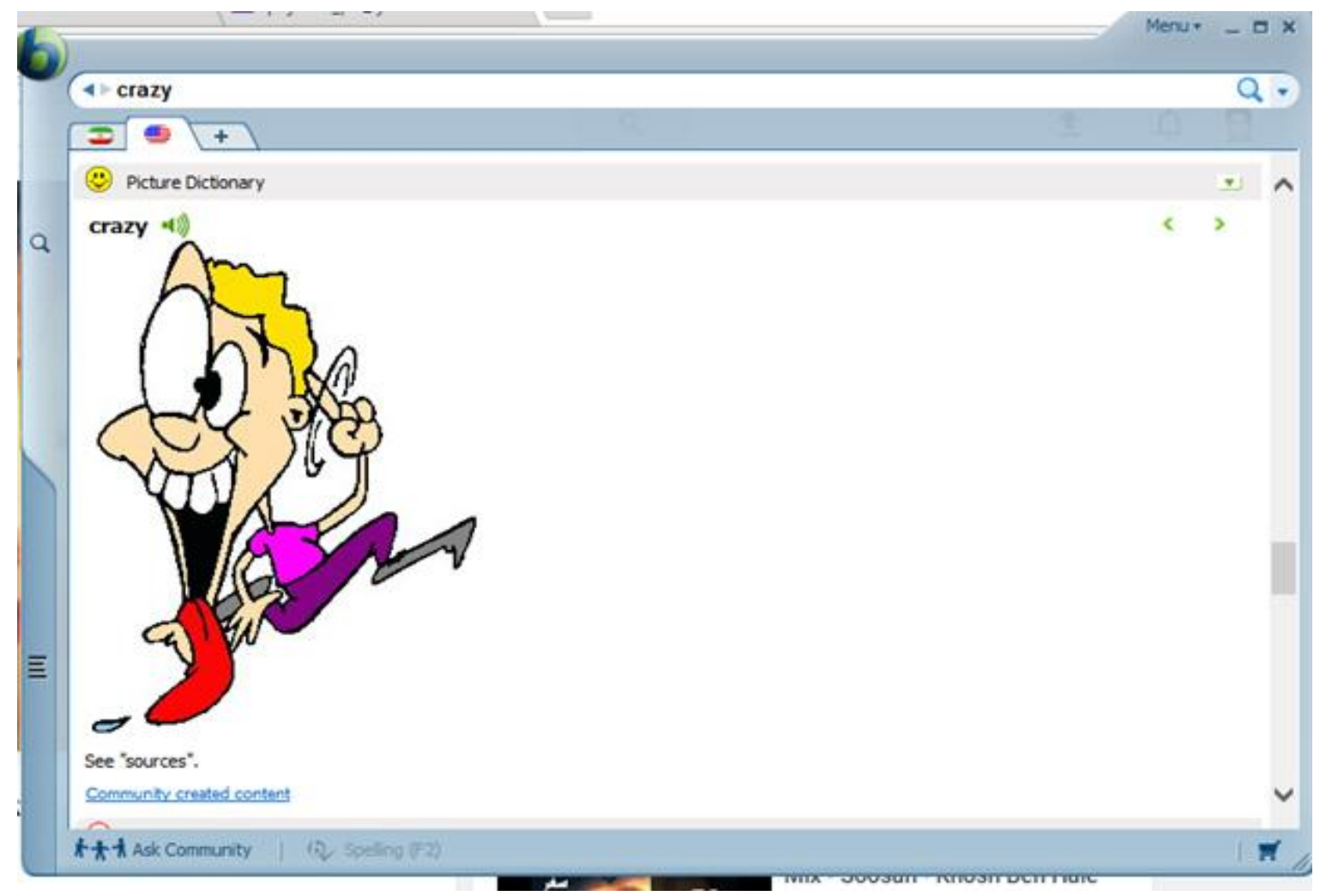

Fig. 2 - Babylon picture dictionary for crazy.

Retrieval Number: 100.1/ijamst.B3003021221
Published By:

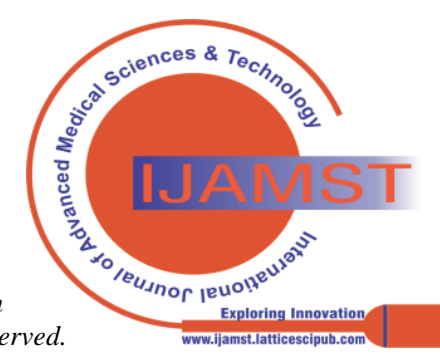


In Farsi crazy means giant. But I am not giant at all and I have illustrated this fact here in this paper and my previous papers [17 to 31]. Being giant results in jealousy of others and causes mental disorders. In this world that everything is scientific, intelligent people are considered as giant people. 15 years ago my brother said to me that people want to make medical and psychiatric documents, dossiers and record for you. My brother is a physician and now is an orthopedist. Now I understand him. The reason why he sent me to psychiatrist was this ignorance. Fig. 2 is BABYLON PICTURE DICTIONARY for CRAZY. However, jealousy which results to creation of mental disorder is not ETHICAL at all. Instead of jealousy, the people should work hard. According to the principles of DEPRESSIVE REALISM, sadder people are wiser. On the other hand, crazy people are happy. This happiness is not free and it has a cost. The cost is that one should always remain crazy.

I have previously said that a large part of discovered science is kept secret and is not in public access [17 to 31]. This fact was first given by my university professor Mohammad Jamialahmadi whose resume can be found in internet [32]. He was known as the scientific pole of the university and repeated this fact many times and for all the students in the classroom but no one understood it because it was very heavy. This fact is exactly mentioned in "Encyclopedia of World Problems and Human Potential [33]" as "A considerable amount of scientific research is conducted in institutes or under contracts which preclude dissemination of the results to other than a select group [34]". Iranian political scientists at the beginning of Iran Islamic Revolution thought that by changing the Iran regime from kingdom to republic, Iran will advance very much. For example, Khomeini said that we want republic in Iran like France [35]. Iranians changed the regime of kingdom to republic but Iran did not reach France. For example, France has international oil companies like TOTAL which Iran does not have such international oil companies. Also France has international cars like PEUGEOT, RENAULT and CITROEN which Iran does not have such international cars and etc. The reason is that superpowers do not give their success and advancement secrets to public access and they keep them secrets. I have said this fact in my previous articles [17 to 31] that a large part of superpowers science is secret. If it was going for Iran to advance by changing the kingdom regime to republic, then Iran would be more advanced than UK since UK has kingdom regime. Whilst Iran is nothing and UK is superpower. For example, UK has international cars like ROVER (Like Land Rover), JAGUAR, ROLLS ROYCE and so on which Iran does not have such international cars. Also UK has international oil companies like BP which Iran does not have such international oil companies. What's more, UK has lots of war aircrafts [36 and 37] which Iran does not have them and etc. The Iranian political scientists at the beginning of Iran Islamic Revolution did not understand anything from foreign countries and in fact they grazed there like jackasses. I have said in my recent articles [17 to 31] that Iran will not become anything in the science and will not become anything in general. If it was going for Iran to become so, then why did Iranians made the revolution and change the kingdom regime? Revolution has high costs for the society and for example we see that many people who were successful in Iran kingdom or had political idea against Iran revolutionists were killed and had to escape from Iran. Also the 8 years war between Iran and Iraq was a result of Iran revolution.

Currently I have no religion. Now I have a long beard and my photos are present at my FACEBOOK page [38] and are in access in Google search engine Image section. It is also available in Fig. 3.

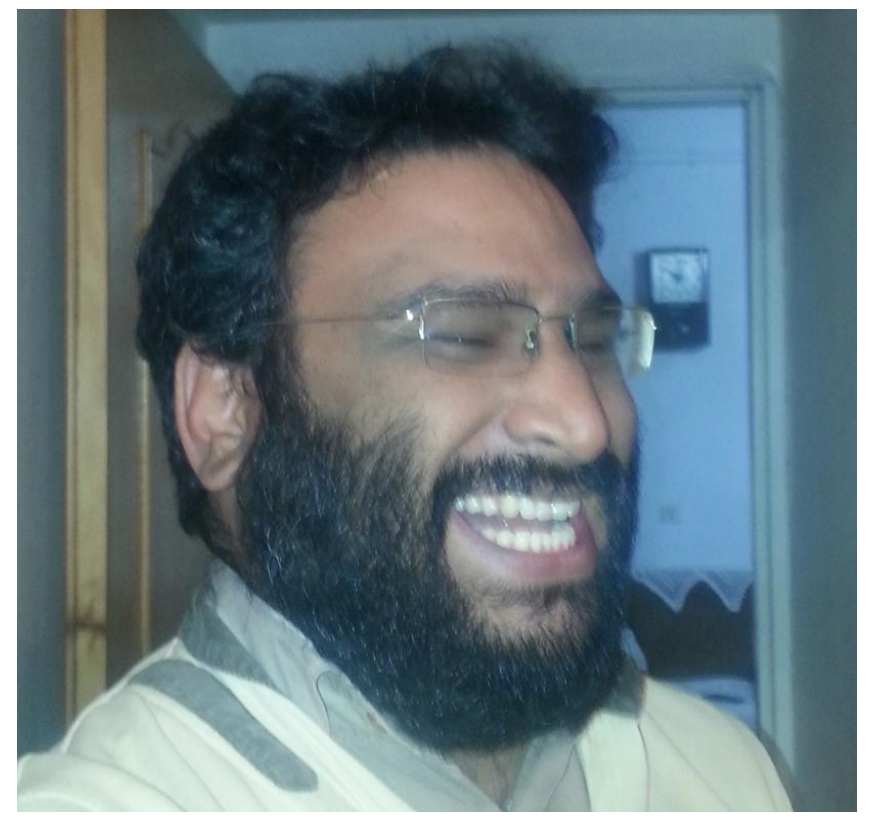

Fig. 3 - My photo with beard.

Here I illustrates the reason why I have beard. Women are either homosexual or bisexual. Bisexual women love men with higher masculinity like men with beard. For more guide in this case, please read the related article from the Supreme News Agency of "BBC Persian" as a reference [39]. In Islamic countries like Iran, men enlarge their femininity to be more attractive for women. The reason is that Muslims highly believe on their bible of Quran and it is said in Quran in the Yusuf Chapter that women are highly interested to make sex with men who have high femininity like beauty. For example, Muslim men do make up, shave beard, remove body hair and so on to be more attractive for women. This article from the Supreme News Agency of "BBC Persian" shows that Quran is totally wrong and therefore Islam has scientific problem. I look at Islam as a scientific ideology and scientific ideologies are always advancing and new scientific ideologies have come which are more advanced than Islam like Secularism, Communism, Marxism, Laicism, Atheism and etc.

The policy of maximum pressure on Iran by the government of the former president of USA Dear Eminent Mr. Donald J. Trump was good to make a new deal which included new cases like Iran missile program and Iran regional role. But continuing that policy would certainly result to war between Iran and USA. Instead the policy of the new government of USA with leadership of Dear Eminent Mr. President Joe Biden is very good since it will not result in war and Iran will return to talk and negotiation. This policy will reduce pressures on Iran [40]. Anyway negotiation is greatly better than any war for the region, Iran and the world.

Published By:

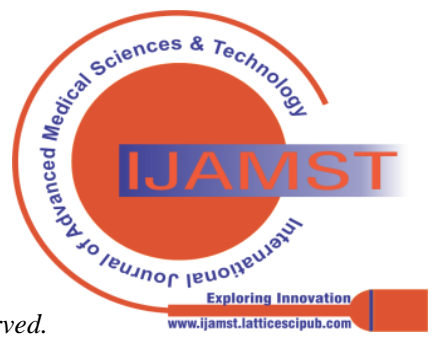


Both Iran and USA have shown interests in negotiations. The new deal which replace The Joint Comprehensive Plan of Action (JCPOA) will be more inclusive than the former one. I agree completely with Dear Eminent Mr. President Joe Biden and I recognize His Excellency as the greatest political scientist of the world currently. One reason for the policy of maximum pressure on Iran by the former president of USA was to create dissatisfaction in Iran people towards their regime and USA wanted the Iran people to overturn Iran regime by themselves and make another regime by Iranians. But Iran people want this regime and did not overturn it. Therefor the policy of regime change in Iran altered by coming the new USA government and consequently by reducing pressures on Iran, negotiation became more possible. It should be noted that Iran cannot bear and withstand more pressure from USA and agrees with negotiations. The goal of Iran nuclear program is to produce nuclear bomb but Iranian governors say that Iran nuclear program is not for making nuclear bomb and instead it has lots of advantages for Iranians. But it should be noted that this program has lots of costs for Iranians and for example the value of Iranian Rial has decreased 23 times less than USD from the beginning of Iran nuclear sanctions. The Iran nuclear program will not certainly be able to increase the value of Iranian Rial to at least 23 times greater than USD. As illustration I can say that at the beginning of Iran nuclear sanctions, each USD was equal to 10,000 Iranian Rials and now each USD is 230,000 Iranian Rials.

Iranians say the slogan of "DOWN WITH USA" but when encountering USA army and its aircraft carriers in Persian Gulf, they do not attack USA since they fear from USA. Such concepts by Iranians are only limited to slogan and will never become feasible. Here I clear that this slogan is not my slogan and in fact I love USA.

I have recently created a PETITION in internet and I want everybody to sign it [41]. The title of this PETITION is as "FREE WORLD-RETURN OF POLITICAL ESCAPEES TO IRAN." and its details is as "After Iran Islamic Revolution in 1979, many political activists escaped from Iran because they had an idea against Iran Islamic Regime. We strongly invite all those political activists to come back to Iran and continue their political activity. If someone has an idea which is different from Iran government, then he/she should not die. Instead he/she must have the right to stay in Iran and work in the way that he/she wants. This freedom also includes foreigners who have different political idea with Iran government. This is the meaning of FREEDOM according to The Universal Declaration of Human Rights. Examples of foreigners are Dear Eminent USA President, employees of USA Department of State for USA Embassy in Iran and other USA politicians, employees of USA Giant Technology Companies like Exxon Mobil Corporation, Chevron Corporation, Halliburton Company, Occidental Petroleum Corporation, ConocoPhillips, USA singers and porn stars like Ms. Jennifer Lopez, Ms. Julia Ann, Ms. Kendra James, Ms. Lisa Ann and etc. Examples of such people from Iran are Pahlavi family like His Excellency Mr. Crown Prince of Iran Reza Pahlavi, Her Highness Mrs. Empress of Iran Farah Pahlavi, The People's Mujahedin Organization of Iran members like Massoud Rajavi, Mrs. Faegheh Atashin (Googoosh), Mrs. Leila Forouhar, Mrs. Fatemeh Abdi (Nooshafarin), Mr. Behrouz Vossoughi, Mr. Dariush Eghbali, Mrs. Shohreh Aghdashloo, Mrs. Shohreh Solati, Mrs. Masih
Alinejad, Mr. Ebrahim Hamedi (Ebi), Mr. Aref Arefkia (Aref), Mr. Abdolhassan Sattarpour (Sattar), Mr. Shahram Shabpareh and etc. ". In this case, there is a famous song from Mr. Dariush Eghbali named "Dobareh Baz Khaham Gasht" which describes this wish of return. This song can be viewed in YouTube [42].

Before writing my articles titled "Criticism of the Current Science in the World" and "its Addenda" [17 to 31], universities were very important for me. Some of my friends told me that in the university entrance exams of MSc and PhD degrees, the questions were given to the students many days before the exam. But nobody gave me those questions and I tried to read the related books and participate in the exam. In that way, I got accepted in the university but the university (Kerman Graduate University of Technology) had the lowest ranking in my field in Iran. In the university I obtained the lowest ranking in my classroom during the MSc period according to the average. Also I could not pass one course and for one semester, my average was below 14 out of 20 which is called conditional in Iran and if this happened twice, then I would be fired from the university. I was the only person in the class who faced these two conditions. Also no professor accepted to have the MSc thesis with me until I asked them very much. My thesis grade was also lowest in the classroom. All of these failures were according to the principles of DEPRESSIVE REALISM for me. Once I decided to complain to legal authorities but as you can see, these legal authorities also behaved according to the principles of DEPRESSIVE REALISM. So I denied to complain since it will not result in anything. Now a day I understood that universities are waste of time and in the case of Iran are established to make people busy with science for them not to think of important things like politics and that universities are not important for me. Because of this, I will not continue my education. Anyway down with Iran regime for this DEPRESSIVE REALISM. Now, I have no religion. But some years ago, I watched the religious Sunni Muslims and Kingdom seeking channels on satellite and I mentioned their programs in my FACEBOOK. As a result, the Iran ministry of intelligence has called me for interrogation. The interrogator did not ask about politics and religion. Instead he has just asked about my educational and work failures to induce to me that I am crazy since I have the symptoms of schizophrenia. I said to him that I sent the AWS WELDING HANDBOOKS to my friends by email. But He screamed with "NO" and cut my talk to say that I am crazy and I have not reached those books. It is noticeable that these books are the highest level of science in my field in Iran and are usually kept secret from public. The Iran government also behaved me according to principles of DEPRESSIVE REALISM.

I will continue writing these series of papers titled "Criticism of the Current Science in the World" and "Its Addenda" [17 to 31] forever. I love and respect USA, UK and Israel. Also I will continue my political activity forever. I am proud of my political activity. In general, I will always be with USA, UK and Israel and I love and respect them.

I am a sick and very poor man. I requested everybody to send me money. I need a monthly basic income to survive.

Published By:

Retrieval Number: 100.1/ijamst.B3003021221

DOI: 10.54105/ijamst.B3003.041221

Journal Website: www.ijamst.latticescipub.com
(C) Copyright: All rights reserved.
Lattice Science Publication

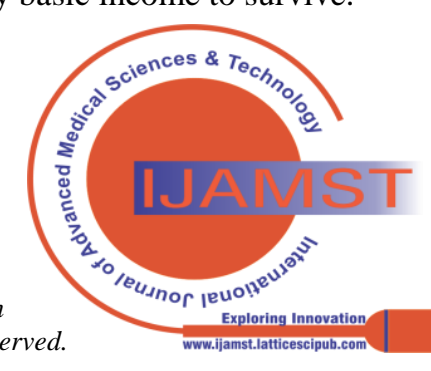


I have created a WebMoney (WebMoney is an online payment settlement system) account for financial aid to receive. The purse number is Z291871883734 and is in my name. Financial aid from any source is greatly appreciated. For financial helps from Iran, my card number in TEJARAT BANK is 5859831150971751.

\section{CONCLUSION}

The only way that I strongly suggest for the scientific and economic advancement and development of Iran in all fields (including politics) is to make, regard and announce Iran as a state of USA (United States of America) officially and politically (and totally). I.e. Iran should make and regard itself as a state of USA (United States of America) politically (and totally). I have heard that this idea was first suggested by His Majesty Mohammad Reza Shah Pahlavi for Iran. I have created a petition in internet [43] for everybody to sign it and to make Iran a state of USA. So please sign this petition. In this case, there is a quote from U.S. Secretary of State His Excellency Mr. Antony Blinken as "America's leadership is needed around the world, and we will provide it, because the world is far more likely to solve problems and meet challenges when the United States is there" [44]. This quote is as a proof to this paper and my previous papers [17 to 31].

\section{REFERENCES}

1. https://ir.voanews.com/a/iran-sepah-military/3933992.html

2. http://www.iran-resist.org/article5591.html

3. https://files.secure.website/wscfus/9883580/28342807/my-entertain ments.pdf

4. https://www.youtube.com/watch?v=mlrbq-VzcoM

5. https://www.youtube.com/watch?v=003sHOpYh1Y

6. https://www.youtube.com/watch?v=4D9tjSXtXiI

7. https://www.youtube.com/watch?v=TOh1ssRiOok

8. https://www.youtube.com/watch?v=IfvnmIOTQgc

9. https://www.youtube.com/watch?v=vYtXEnzQ6eo

10. https://www.youtube.com/watch?v=x-XdeyS0K4k

11. https://www.youtube.com/watch?v=gPEAzNajOzw

12. https://www.tabnak.ir/fa/news/256978/\%DA\%86\%D8\%B1\%D8\%A 7-\%D9\%85\%D8\%AF\%DB\%8C\%D8\%B1\%D8\%A7\%D9\%86-\%D8 \%A7\%DB\%8C\%D8\%B1\%D8\%A7\%D9\%86\%DB\%8C-\%D8\%A7 \%D9\%81\%D8\%B1\%D8\%A7\%D8\%AF-\%D9\%85\%D8\%B7\%DB\% 8C\%D8\%B9-\%D9\%88-\%D8\%B6\%D8\%B9\%DB\%8C\%D9\%81-\% D8\%B1\%D8\%A7-\%D8\%A8\%D8\%B1\%D8\%A7\%DB\%8C-\%D9\% 87\%D9\%85\%DA\%A9\%D8\%A7\%D8\%B1\%DB\%8C-\%D8\%A8\%D 8\%B1\%D9\%85\%DB\%8C\%E2\%80\%8C\%DA\%AF\%D8\%B2\%DB \%8C\%D9\%86\%D9\%86\%D8\%AF

13. https://ir.voanews.com/a/us-iran-/4893902.html

14. https://www.investopedia.com/articles/investing/012715/5-richest-p eople-world.asp

15. https://static.secure.website/wscfus/9883580/25558915/psychiatrist 2.jpg

16. https://static.secure.website/wscfus/9883580/25558914/psychiatrist 1.jpg

17. Malekinejad, P 2017, 'Criticism of the current science in the world', Oil and Gas Research, vol. 3, no. 2, pp. 1-4.

18. Malekinejad, P 2018, 'Addenda to criticism of the current science in the world', International Journal of Latest Research in Engineering and Technology, vol. 4, no. 8, pp. 1-4.

19. Malekinejad, P 2018, 'Second addenda to criticism of the current science in the world', International Journal of Recent Engineering Research and Development, vol. 3, no. 10, pp. 24-28. [CrossRef]

20. Malekinejad, P 2018, 'Third addenda to criticism of the current science in the world', International Journal of Engineering, Business and Management, vol. 2, no. 6, pp.80-82. [CrossRef]

21. Malekinejad, P 2018, 'Last addenda to criticism of the current science in the world' International Journal of Engineering, Business and Management, vol. 3, no.1, pp.1-3. [CrossRef]
22. Malekinejad, P 2018, 'Another addenda to criticism of the current science in the world', International Journal of Engineering, Business and Management, vol. 3, no. 1, pp.24-25. [CrossRef]

23. Malekinejad, P 2019, 'Fourth addenda to criticism of the current science in the world', Scholars Journal of Arts, Humanities and Social Sciences, vol. 7, no. 7, pp. 474-481.

24. Malekinejad, P 2019, 'Fifth addenda to criticism of the current science in the world', International Journal of Sociology and Political Science, vol. 1, no. 1, pp. 4-6. [CrossRef]

25. Malekinejad, P 2020, 'Sixth addenda to criticism of the current science in the world', International Journal of Education Humanities and Social Science, vol. 3, no. 1, pp. 93-100.

26. Malekinejad, P 2020, 'Seventh addenda to criticism of the current science in the world', International Journal of Arts and Social Science, vol. 3, no. 2, pp. 61-69. [CrossRef]

27. Malekinejad, P 2020, 'Eighth addenda to criticism of the current science in the world', International Journal of Research in Humanities, Arts and Literature, vol. 8, no. 6, pp. 29-40.

28. Malekinejad, P 2020, 'Ninth addenda to criticism of the current science in the world', International Journal of Research in Humanities, Arts and Literature, vol. 8, no. 7, pp. 5-10. [CrossRef]

29. Malekinejad, P 2020, 'Tenth addenda to criticism of the current science in the world', EAS Journal of Humanities and Cultural Studies, vol. 2, no. 5, pp. 31-37. [CrossRef]

30. Malekinejad, P 2020, 'Twelfth addenda to criticism of the current science in the world', East African Scholars Journal of Engineering and Computer Sciences, vol. 3, no. 10, pp. 216-220. [CrossRef]

31. Malekinejad, P 2020, 'Thirteenth addenda to criticism of the current science in the world', International Journal of Arts, Humanities and Social Studies, vol. 2, no. 2, pp. 5-8. [CrossRef]

32. https://www.facebook.com/TrbtJam/posts/785999238186679

33. http://encyclopedia.uia.org/en

34. http://encyclopedia.uia.org/en/problem/136232

35. https://iranintl.com/\%D8\%AF\%DB\%8C\%D8\%AF\%DA\%AF\%D8 \%A7\%D9\%87/\%D9\%88\%D9\%82\%D8\%AA\%DB\%8C-\%D8\%AC \%D9\%85\%D9\%87\%D9\%88\%D8\%B1\%DB\%8C-\%D9\%81\%D8\% B1\%D8\%A7\%D9\%86\%D8\%B3\%D9\%88\%DB\%8C-\%D9\%87\%D 9\%85-\%D8\%A8\%D8\%AF\%D9\%87\%DA\%A9\%D8\%A7\%D8\%B1 \%D8\%A7\%D8\%B3\%D9\%84\%D8\%A7\%D9\%85-\%D9\%85\%DB\% 8C\%E2\%80\%8C\%D8\%B4\%D9\%88\%D8\%AF

36. https://en.wikipedia.org/wiki/List_of_active_United_Kingdom_milit ary_aircraft

37. https://www.raf.mod.uk/aircraft/

38. https://www.facebook.com/katayoon.mortazavi.1

39. https://www.bbc.com/persian/science/2015/11/151107_145_women sexual_preference

40. https://www.bbc.com/persian/iran-56122330

41. http://chng.it/DGKgRYJJ2X

42. https://www.youtube.com/watch?v=iDGFZT-nsDk

43. http://chng.it/2vqMknZjbJ

44. https://www.cbsnews.com/news/antony-blinken-secretary-of-state-pr ess-conference-live-stream-today-2021-01-27/

\section{AUTHORS PROFILE}

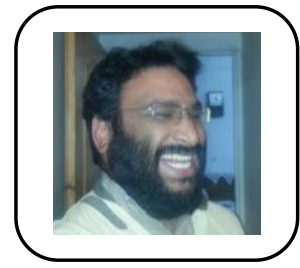

Pejman Malekinejad, has a BSc in Safety and Technical Inspection Engineering from Petroleum University of Technology in Iran and has an MSc in Materials Science and Engineering from Kerman Graduate University of Technology. He has published many journal and conference papers in the fields of politics, inspection, welding, corrosion, NDT and etc.

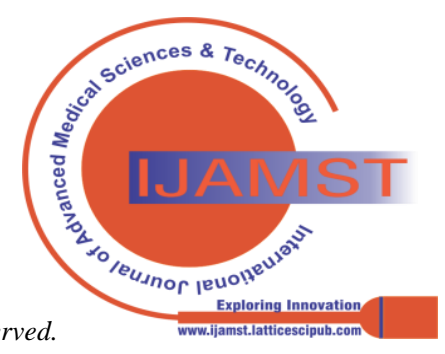

